\title{
Pandemic influenza $\mathrm{A} / \mathrm{H} 1 \mathrm{~N} 1$ virus infection and $T N F, L T A, I L 1 B, I L 6, I L 8$, and CCL polymorphisms in Mexican population: a case-control study
}

Guadalupe Morales-García ${ }^{1 \dagger}$, Ramcés Falfán-Valencia ${ }^{2}$, Román Alejandro García-Ramírez ${ }^{1 \dagger}$, Ángel Camarena ${ }^{2}$, Alejandra Ramirez-Venegas², Manuel Castillejos-López², Martha Pérez-Rodríguez', César González-Bonillaª , Concepción Grajales-Muñíz ${ }^{3}$, Víctor Borja-Aburto ${ }^{3}$ and Juan Manuel Mejía-Aranguré ${ }^{*}$

\begin{abstract}
Background: Some patients have a greater response to viral infection than do others having a similar level of viral replication. Hypercytokinemia is the principal immunopathological mechanism that contributes to a severer clinical course in cases of influenza A/H1N1. The benefit produced, or damage caused, by these cytokines in severe disease is not known. The genes that code for these molecules are polymorphic and certain alleles have been associated with susceptibility to various diseases. The objective of the present study was to determine whether there was an association between polymorphisms of TNF, LTA, ILIB, ILG, IL8, and CCL1 and the infection and severity of the illness caused by the pandemic A/H1N1 in Mexico in 2009.
\end{abstract}

Methods: Case-control study. The cases were patients confirmed with real time PCR with infection by the A/H1N1 pandemic virus. The controls were patients with infection like to influenza and non-familial healthy contacts of the patients with influenza. Medical history and outcome of the disease was registered. The DNA samples were genotyped for polymorphisms TNF rs361525, rs1800629, and rs1800750; LTA rs909253; IL1B rs16944; IL6 rs1818879; IL8 rs4073; and CCL1 rs2282691. Odds ratio (OR) and the 95\% confidence interval (95\% Cl) were calculated. The logistic regression model was adjusted by age and severity of the illness in cases.

Results: Infection with the pandemic A/H1N1 virus was associated with the following genotypes: TNF rs361525 AA, $\mathrm{OR}=27.00 ; 95 \% \mathrm{Cl}=3.07-1248.77) ; \mathrm{LTA}$ rs909253 AG $(\mathrm{OR}=4.33,95 \% \mathrm{Cl}=1.82-10.32) ;$ TNF rs $1800750 \mathrm{AA}$ $(\mathrm{OR}=4.33,95 \% \mathrm{Cl}=1.48-12.64)$; additionally, LTA rs909253 AG showed a limited statistically significant association with mortality $(p=0.06, O R=3.13)$. Carriers of the TNF rs 1800629 GA genotype were associated with high levels of blood urea nitrogen $(p=0.05)$; those of the TNF rs1800750 AA genotype, with high levels of creatine phosphokinase $(p=0.05)$. The IL1B rs16944 AA genotype was associated with an elevated number of leukocytes $(\mathrm{p}<0.001)$ and the IL8 rs4073 AA genotype, with a higher value for $\mathrm{P}_{\mathrm{a}} \mathrm{O}_{2} \mathrm{~mm} \mathrm{Hg}$.

Conclusion: The polymorphisms of genes involved in the inflammatory process contributed to the severity of the clinical behavior of infection by the pandemic influenza A/H1N1 virus.

Keywords: TNF, IL1B, IL8, IL6, LTA, CCL1, Influenza AH1N1

\footnotetext{
* Correspondence: juan.mejiaa@imss.gob.mx

${ }^{\dagger}$ Equal contributors

${ }^{1}$ Coordinación de Investigación en Salud, Instituto Mexicano del Seguro

Social (IMSS), Torre Academia Nacional de Medicina 4to piso,

Av. Cuauhtémoc 330, 06720 México, DF, México

Full list of author information is available at the end of the article
} 


\section{Background}

The influenza A/H1N1 virus pandemic of 2009 started in Mexico and then spread worldwide, with an alert level of pandemic phase 6 declared by the World Health Organization (WHO) in June of that year [1]. Although the majority of those infected by the influenza $\mathrm{A} / \mathrm{H} 1 \mathrm{~N} 1$ virus presented mild symptoms that were self-limiting, a subgroup of patients followed an adverse clinical course, thus requiring a greater level of medical attention and more aggressive management [2]. In Mexico the lethal rate was estimated to be $1.2 \%$ for cases of influenza-like illness (ILI) and 5\% for confirmed cases of influenza A/H1N1 [3]. Some co-morbidities (e.g., immunosuppression, pre-existing pulmonary disease, cardiac disease, diabetes, asthma that requires regular medical attention, smoking, and obesity) have been demonstrated to increase the risk of hospitalization for infection with influenza $\mathrm{A} / \mathrm{H} 1 \mathrm{~N} 1[4,5]$. The risk is also augmented in the second and third trimesters of pregnancy and when treatment with oseltamivir is prescribed five days after the onset of the illness [6]. In addition, the results of certain laboratory tests (e.g., lactate dehydrogenase (LDH), $>600 \mathrm{IU} / \mathrm{L}$; hypoxemia $\left(\mathrm{P}_{\mathrm{a}} \mathrm{O}_{2},<60 \mathrm{~mm} \mathrm{Hg}\right)$; C-reactive protein (CRP), $10 \mathrm{mg} / \mathrm{dl}$; and leukopenia $<5000 / \mathrm{mm}^{3}$ ) have been associated with greater mortality from infection by influenza $\mathrm{A} / \mathrm{H} 1 \mathrm{~N} 1$ virus $[7,8]$.

Through experimental and clinical studies, it has been determined that the most important pathological mechanism in this infection is systemic dysregulation of the inflammatory response, which is correlated with the severity and progression of the illness $[9,10]$. The secretion of cytokines by infected cells appears to be necessary for the initiation of the immunological response that controls the replication of the virus [11]; in addition, the presence of immunopathological mechanisms, such as hypercytokinemia ("cytokine storm"), generally is considered to contribute to the severest evolution of the infection [11-13]. Elevated levels of pro-inflammatory cytokines and chemokines (e.g., TNF $\alpha$, IFN $\gamma$, IL-1, IL-6, IL-8, IL-9, IL-12 IL-15, and IL-17) have been found, up to ten days after the onset of symptoms, in the plasma of patients with acute respiratory distress syndrome (ARDS) caused by influenza A/H1N1 [9,10,14]. The genes that code for these molecules are polymorphic and certain alleles have been associated with susceptibility to various diseases that cover a wide range of pathologies, from infectious to oncological, including pulmonary and systemic diseases [15-30]. The role that the polymorphisms of the genes encoding these cytokines play in the severity of the disease is not clear.

The extensive polymorphism of these molecules may be associated with the high mortality rate during the 2009 influenza A/H1N1 pandemic in Mexico. Because we think that genetic factors of the host may influence the nature and intensity of the inflammatory immune response, the objective of this study was to determine whether the polymorphisms of genes that are associated with inflammation may be associated with the development of the infection and with the clinical severity in Mexican mestizo patients with influenza A/H1N1.

\section{Methods}

The rapid QuickVue Influenza A+B test (Quidel, San Diego, CA, USA) was used to analyze the nasopharyngeal swab samples obtained from the patients in 94 cases of suspected infection by influenza $\mathrm{A} / \mathrm{H} 1 \mathrm{~N} 1$, following the recommendations for collection and testing of the U.S. Centers for Disease Control and Prevention (CDC) and of the WHO [31,32]. The patients were then separated into two groups: those positive for influenza $\mathrm{A} / \mathrm{H} 1 \mathrm{~N} 1$ (A/H1N1 group) and those negative, as having influenza-like illness (ILI group). A total of 44 patients were positive for the influenza $\mathrm{A} / \mathrm{H} 1 \mathrm{~N} 1$ virus (A/H1N1 group); the remaining 50 patients who had tested negative for the influenza $\mathrm{A} / \mathrm{H} 1 \mathrm{~N} 1$ virus, were diagnosed as having influenza-like illness (ILI).

In addition, a group of 176 asymptomatic healthy contacts (AHC group) voluntarily participated in the study. Those in the AHC group, although not biologically related to any patient, were in personal contact with at least one of the patients during the period of the illness. To ensure that those in the AHC group had been exposed to the virus, their titers of antiinfluenza $\mathrm{A} / \mathrm{H} 1 \mathrm{~N} 1$ antibodies were determined. To evaluate the presence of antibody, we use haemagglutination inhibition technique (HAI); contacts exhibited significant titers of specific anti-A/H1N1 antibodies, supporting the fact that they were in contact with the $\mathrm{A} / \mathrm{H} 1 \mathrm{~N} 1$ virus. By serially diluted aliquots of serum samples; those individuals with titers greater than 1:16 were considered positive for $\mathrm{A} / \mathrm{H} 1 \mathrm{~N} 1$ infection/exposure. The two patient groups and the AHC group were Mexican mestizos (age range: 18-85 years). All patients suspected of influenza A/H1N1 infection were treated with anti-viral therapy (oseltamivir) upon admittance at the hospital.

The information collected in this study included demographic, clinical history, laboratory test data, pharmacological treatment, and follow-up. This study was approved by the Institutional Committee of Science and Bioethics of the National Institute of Respiratory Diseases (code B05-10). The study protocol was explained to all participants and signed informed consent was duly obtained from each participant. This information was obtained by means of a clinical form in accord with Official Mexican Standards Mexicana NOM-168-SSA1-1998; topics covered included age; gender; tobacco smoking; body-mass index (BMI; patients with $\mathrm{BMI}>30 \mathrm{k} / \mathrm{m}^{2}$ ); and disease morbidity (pulmonary, 
hepatic, renal, cardiac, neurological diseases, diabetes mellitus, hypertension, and cancer). The symptoms evaluated were fever, cough, rhinorrhea, dyspnea, nasal congestion, thoracic pain, headache, diarrhea, and vomiting. The begin of anti-viral therapy was evaluated in relation to the days with previous symptomatology. The laboratory parameters included were leukocyte titer; lactate dehydrogenase (LDH); creatine phosphokinase (CPK); blood urea nitrogen (BUN); and arterial gases (with $\mathrm{P}_{\mathrm{a}} \mathrm{O}_{2}<60 \mathrm{~mm} \mathrm{Hg}$ defined as severe disease). Pneumonia was verified by radiological findings. All patients admitted to the intensive care unit (ICU) and those put on assisted mechanical ventilation (AMV) were identified.

\section{Genotyping of allelic variants (single nucleotide polymorphism, SNPs)}

The DNA samples were genotyped for polymorphisms TNF rs361525, rs1800629, and rs1800750; LTA rs909253; IL1B rs16944; IL6 rs1818879; IL8 rs4073; and CCL1 rs2282691 using Taqman commercial probes (Apliedd Biosystems, USA) the primers listed in Table 1. In brief, the procedure for the real time PCR was the following: 15 ng DNA; $15 \mu \mathrm{L}$ of Taqman universal PCR master mix (Roche NJ, USA) and $6.5 \mu \mathrm{L}$ of each probes. The conditions for amplification were the following: $94^{\circ} \mathrm{C}(3 \mathrm{~min})$, $61^{\circ} \mathrm{C}(1 \mathrm{~min})$, and $72^{\circ} \mathrm{C}(1 \mathrm{~min})$; followed by 35 cycles of $94^{\circ} \mathrm{C}(1 \mathrm{~min}), 61^{\circ} \mathrm{C}(1 \mathrm{~min})$, and $72^{\circ} \mathrm{C}(1 \mathrm{~min}$,$) ; and a final$ cycle of $94^{\circ} \mathrm{C}(1 \mathrm{~min}), 61^{\circ} \mathrm{C}(1 \mathrm{~min})$, and $72^{\circ} \mathrm{C}(5 \mathrm{~min})$. The genetic data for the SNPs were analyzed and are listed in Table 2.

\section{Analysis}

When the polymorphisms were evaluated, the ancestral genotype was used for comparison. The odds ratio (OR) and the $95 \%$ confidence interval $(95 \% \mathrm{CI})$ were calculated. In the logistic regression model, the OR was adjusted by age and severity of the illness. The $x^{2}$ test was used to evaluate the differences between the proportions of the groups. The differences among the clinical parameters, continuous variables, and polymorphisms
Table 2 Genetic data of the single nucleotide polymorphisms (SNPs) analyzed

\begin{tabular}{|c|c|c|c|c|}
\hline \multirow[t]{2}{*}{ SNP } & \multicolumn{4}{|c|}{ Gene } \\
\hline & Symbol & Location & Position & Alleles \\
\hline rs1800750 & TNF & -376 & Promoter & $\mathrm{G} / \mathrm{A}$ \\
\hline rs1800629 & $"$ & -308 & Promoter & $\mathrm{G} / \mathrm{A}$ \\
\hline rs361525 & $"$ & -238 & Promoter & $\mathrm{G} / \mathrm{A}$ \\
\hline rs909253 & LTA & +252 & Intronic & $\mathrm{C} / \mathrm{T}$ \\
\hline rs16944 & IL1B & -511 & Promoter & $\mathrm{G} / \mathrm{A}$ \\
\hline rs1818879 & $1 L 6$ & 5845 & $3^{\prime} U T R$ & $\mathrm{~A} / \mathrm{G}$ \\
\hline rs4073 & IL8 & -251 & Promoter & $\mathrm{A} / \mathrm{T}$ \\
\hline rs2282691 & CCL1 & 29712422 & Intronic & $\mathrm{A} / \mathrm{T}$ \\
\hline
\end{tabular}

were evaluated by using the Mann-Whitney $U$ test. Software packages SPSS 19 (IBM, Chicago, IL) and Epi-Info $6.04 \mathrm{~b}$ were used (Atlanta, CDC).

\section{Results}

The patients were separated into two groups depending whether they were positive or negative for influenza $\mathrm{A} / \mathrm{H} 1 \mathrm{~N} 1$, thereby forming the groups, influenza $\mathrm{A} / \mathrm{H} 1 \mathrm{~N} 1$ and ILI, respectively. In both the $\mathrm{A} / \mathrm{H} 1 \mathrm{~N} 1$ and ILI groups, the majority was male $(68.0 \%$ and $58.0 \%$, respectively), whereas in the AHC group, 61.93\% were female. The mean age of the A/H1N1 and ILI groups was $<45$ years $(68.18 \%$ and $60.0 \%$, respectively), compared to that of the AHC group, $56.82 \%$ of who were $45-64$ years of age.

The data concerning the demographics, co-morbidities, and symptomatology for both groups of patients are presented in Table 3. Interestingly, the mortality was higher for patients with infection by influenza A/H1N1 than for those with ILI $(34.09 \%$ vs. 4.0\%, respectively; $\mathrm{P}<0.001)$; similarly, hospitalization in the ICU was more frequent for the influenza $\mathrm{A} / \mathrm{H} 1 \mathrm{~N} 1$ group $(54.55 \%$ vs. $30.0 \%$, respectively; $\mathrm{p}=0.01)$. No statistically significant differences were found for any of the other variables analyzed. Of the influenza $\mathrm{A} / \mathrm{H} 1 \mathrm{~N} 1$ patients, $93.3 \%$ had radiographic signs of pulmonary compromise, with a statistically significant difference

Table 1 DNA samples were genotyped by using Taqman commercial probes

\begin{tabular}{ll}
\hline Gene (reference SNP) & Probe \\
\hline$T N F($ rs1800750) & GAGGCAATAAGACCCCCCTCGGAATC[A/G]GAGCAGCTGTCAATTGCAGGAGCT \\
\hline$T N F($ rs1800629) & GAGGCAATAGGTTTGAGGGGCATG[A/G]GGACGGGGTTCAGCCTCCAGGGTCC \\
\hline TNF (rs361525) & GGCCCAGAAGACCCCCCTCGGAATC[A/G]GAGCAGGGAGGATGGGGAGTGTGA \\
\hline LTA (rs909253) & AAGCCTTAAAACCTAGGGCATACA[C/T]TGATAATTCACCCTCCAGGGTCCGTT \\
\hline IL1B (rs16944) & TACCTTGGGTGCTGTTCTCTGCCTC[G/A]GGAGCTCTCTGTCAATTGCAGGAGC \\
\hline IL6 (rs1818879) $(\mathrm{rs} 4073)$ & AGACGAGCTGGGCGCAGTGGCTCAC[A/G]CCTATAATCCCAGCACTTGGGAGG \\
\hline$C C 1$ (rs2282691) & TTATCTAGAAATAAAAAAGCATACA[A/TTTGATAATTCACCAAATTGTGGAGC \\
\hline
\end{tabular}


Table 3 Demographical and clinical characteristics of influenza A/H1N1 patients, influenza-like illness (ILI) patients, and healthy control subjects

\begin{tabular}{|c|c|c|c|c|}
\hline Characteristic & $\frac{\text { A/H1N1 patients }}{\text { (Total: 44) }}$ & $\frac{\text { ILI patients }}{\text { (Total: } 50)}$ & $\frac{\text { Healthy controls }}{\text { (Total: } 176)}$ & $p$ \\
\hline & n (\%) & n (\%) & n (\%) & \\
\hline \multicolumn{5}{|l|}{ Sex } \\
\hline Male & $30(68.18)$ & $29(58.0)$ & $67(38.07)$ & \\
\hline Female & $14(31.82)$ & $21(42.0)$ & $109(61.93)$ & \\
\hline \multicolumn{5}{|l|}{ Age } \\
\hline$<45$ & $30(68.18)$ & $30(60.0)$ & $54(30.68)$ & \\
\hline $45-64$ & $11(25.00)$ & $13(26.0)$ & $100(56.82)$ & \\
\hline$\geq 65$ & $3(6.82)$ & $7(14.0)$ & $22(12.50)$ & \\
\hline $\mathrm{BMI} \geq 30$ & $18(40.91)$ & $21(42.0)$ & $46(26.42)$ & \\
\hline Mortality & $15(34.09)$ & $2(4.0)$ & & $<0.001^{*}$ \\
\hline $\mathrm{P}_{\mathrm{a}} \mathrm{O}_{2}<60 \mathrm{~mm} \mathrm{Hg}$ (severe) & $19(43.18)$ & $24(48.0)$ & & \\
\hline ICU & $24(54.55)$ & $15(30.0)$ & & $0.01^{*}$ \\
\hline \multicolumn{5}{|l|}{ Co-morbidities } \\
\hline Neurological disease & $25(56.82)$ & $22(44.0)$ & & \\
\hline Asthma & $2(4.55)$ & $6(12.0)$ & & \\
\hline Cancer & $1(2.27)$ & $2(4.0)$ & & \\
\hline Hypertension & $8(18.18)$ & $7(14.0)$ & & \\
\hline Smoking & $21(47.73)$ & $29(58.0)$ & & \\
\hline \multicolumn{5}{|l|}{ Symptomatology } \\
\hline Fever $\left(>38^{\circ} \mathrm{C}\right)$ & $33(75.00)$ & $42(84.0)$ & & \\
\hline Cough & $23(52.27)$ & $31(62.0)$ & & \\
\hline Nasal Congestion & $5(11.36)$ & $2(4.0)$ & & \\
\hline Rhinorrhea & $12(27.27)$ & $20(40.0)$ & & \\
\hline Dyspnea & $33(75.00)$ & 35 (70.0) & & \\
\hline
\end{tabular}

*When comparing A/H1N1 patients vs. ILI patients. BMI: Body mass index; $\mathrm{P}_{2} \mathrm{O}_{2}$ : partial pressure of oxygen in arterial blood; ICU: Intensive Care Unit. Results were considered statistically significant when $\mathrm{P}$ was $<0.05$.

between the two groups of patients $(\mathrm{p}=0.043$; data not shown).

\section{Analysis of genetic association}

Genotyping was carried out for eight SNPs from six genes, the protein products of which have been associated with inflammatory processes. The genetic information of the polymorphisms that were evaluated is presented in Table 4. An appreciation of the genetic contribution to the risk of infection by influenza $A / H 1 N 1$ was obtained by evaluating genotype and alleles of both patient groups and comparing the frequencies of the genotypes and alleles with those of the AHC group.

For the $\mathrm{A} / \mathrm{H} 1 \mathrm{~N} 1$ and $\mathrm{AHC}$ groups, of the eight SNPs used, 24 genotype products were generated; in the ILI group, only 23 genotypes were determined, as the genotype AA does not exist for the rs361525 of the gene $T N F$. For the $\mathrm{A} / \mathrm{H} 1 \mathrm{~N} 1$ group, five genotypes associated with risk were identified ( $\mathrm{p}<0.05$; OR $>2.0$ ). Of particular interest was the finding of homozygous A genotype in SNPs rs361525 and rs1800750 in TNF, both with values of $\mathrm{OR}>5.0$. In addition, the genotypes rs2282691 AA, rs4073 AT, and rs909253 CT (CCL1, IL8, and LTA, respectively) demonstrated statistically significant association with risk. For the ILI group, three of the five associations previously reported for the A/H1N1 group were found. It is of note that these associations, which coincided in both patient groups, showed statistically significant data ( $p$ values and OR) that were very similar. On the other hand, our findings demonstrated the existence of three genotypes with association to protection (p <0.05; OR <1.0): IL1B rs16944 AA, LTA rs909253, and TNF rs1800750 GG, in both patient groups, as compared to the AHC group (Table 4).

In the analysis of alleles, two signs that showed statistically significant association with risk were found: allele A of rs2282691 of CCL1 was shown to be increased in both patient groups $(\mathrm{A} / \mathrm{H} 1 \mathrm{~N} 1, \mathrm{p}<0.05$; ILI, $\mathrm{p}<0.01)$, when the allelic frequency (AF) of each patient group was compared with that of the AHC group ( $\mathrm{OR}=2.15$ 
Table 4 Genetic frequency of the genotypes of eight SNPs in six genes and their association with infection by influenza $\mathrm{A} / \mathrm{H} 1 \mathrm{~N} 1$ virus

\begin{tabular}{|c|c|c|c|c|c|c|c|c|c|}
\hline \multirow{2}{*}{$\begin{array}{l}\text { Gene and } \\
\text { genotype }\end{array}$} & \multicolumn{9}{|c|}{ Genetic frequency } \\
\hline & A/H1N1 group & AHC group & $p$ & OR & $95 \% \mathrm{Cl}$ & ILI group & $p$ & OR & $95 \% \mathrm{Cl}$ \\
\hline \multicolumn{10}{|c|}{ CCL1 rs2282691 } \\
\hline AA & 0.643 & 0.402 & 0.0085 & 2.67 & $1.26-5.81$ & 0.630 & 0.0096 & 2.53 & $1.23-5.30$ \\
\hline TA & 0.286 & 0.456 & & & & 0.304 & & & \\
\hline$\pi$ & 0.071 & 0.142 & & & & 0.065 & & & \\
\hline \multicolumn{10}{|l|}{ IL1B rs16944 } \\
\hline GA & 0.535 & 0.449 & & & & 0.583 & & & \\
\hline GG & 0.442 & 0.364 & & & & 0.375 & & & \\
\hline $\mathrm{AA}$ & 0.023 & 0.188 & 0.015 & 0.10 & $0.00-0.66$ & 0.042 & 0.024 & 0.19 & $0.02-0.79$ \\
\hline \multicolumn{10}{|l|}{ IL8 rs4073 } \\
\hline AT & 0.659 & 0.445 & 0.0231 & 2.40 & $1.12-5.32$ & 0.500 & & & \\
\hline AA & 0.244 & 0.396 & & & & 0.386 & & & \\
\hline$\pi$ & 0.098 & 0.159 & & & & 0.114 & & & \\
\hline \multicolumn{10}{|l|}{ IL6 rs1818879 } \\
\hline GG & 0.439 & 0.268 & & & & 0.381 & & & \\
\hline AG & 0.390 & 0.530 & & & & 0.452 & & & \\
\hline AA & 0.171 & 0.202 & & & & 0.167 & & & \\
\hline \multicolumn{10}{|l|}{ LTA rs909253 } \\
\hline CT & 0.535 & 0.244 & 0.0004 & 3.56 & $1.68-7.54$ & 0.540 & 0.00014 & 3.63 & $1.79-7.38$ \\
\hline$\pi$ & 0.302 & 0.488 & 0.0432 & 0.45 & $0.20-0.97$ & 0.320 & $0.0517^{*}$ & 0.49 & $0.24-1.00$ \\
\hline CC & 0.163 & 0.267 & & & & 0.140 & & & \\
\hline \multicolumn{10}{|l|}{ TNF } \\
\hline \multicolumn{10}{|l|}{ rs361525 } \\
\hline GG & 0.818 & 0.884 & & & & 0.894 & & & \\
\hline $\mathrm{AA}$ & 0.136 & 0.006 & 0.00031 & 27.0 & $3.07-1248.77$ & 0.000 & & & \\
\hline GA & 0.045 & 0.110 & & & & 0.106 & & & \\
\hline \multicolumn{10}{|l|}{ rs1800629 } \\
\hline GG & 0.932 & 0.946 & & & & 0.911 & & & \\
\hline $\mathrm{GA}$ & 0.068 & 0.054 & & & & 0.089 & & & \\
\hline $\mathrm{AA}$ & 0.000 & 0.000 & & & & & & & \\
\hline \multicolumn{10}{|l|}{ rs1800750 } \\
\hline GG & 0.789 & 0.949 & 0.0035 & 0.20 & $0.06-0.66$ & 0.830 & 0.0116 & 0.26 & $0.08-0.84$ \\
\hline AA & 0.158 & 0.028 & 0.005 & 6.41 & $1.51-27.92$ & 0.128 & 0.0128 & 5.00 & $1.20-21.61$ \\
\hline GA & 0.053 & 0.023 & & & & 0.043 & & & \\
\hline
\end{tabular}

A/H1N1 group: patient infected with influenza A/H1N1 virus; AHC group: asymptomatic, healthy contacts; ILI group: patients with influenze-like illness; OR: odds ratio; $\mathrm{Cl}$ : confidence interval. Results were considered statistically significant when $\mathrm{p}$ was $<0.05$.

and 2.11, respectively). Also, rs1800750 allele A, one of the three polymorphisms evaluated for $T N F$, showed a similar behavior, that is, an association with risk in both patient groups $(\mathrm{A} / \mathrm{H} 1 \mathrm{~N} 1, \mathrm{p}<0.01$; ILI, $\mathrm{p}<0.01)$. No other association was found for the remaining six SNPs analyzed (Table 5).

\section{Association of genotypes with clinical variables Mortality}

The genotype AG of rs909253 in LTA showed a tendency to be associated with mortality $(\mathrm{OR}=3.13)$, with $\mathrm{p}=0.06$ just above the limit of statistical significance. Table 6 presents the data for the different genotypes evaluated with respect to mortality. The data corresponding to the allelic OR were carried out for both alleles; however, only those carried out for the ancestral allele are shown. No data for the remaining alleles or genotypes studied were statistically significant. The logistic regression analysis, after adjusting for levels of $\mathrm{P}_{\mathrm{a}} \mathrm{O}_{2}$ and for admission to the ICU, showed no statistically significant association between the genotypes and mortality. 
Table 5 Risk of influenza A/H1N1 infection in relation to the different polymorphisms studied

\begin{tabular}{|c|c|c|c|}
\hline \multirow[t]{2}{*}{ Gen/allele } & \multicolumn{3}{|c|}{ Risk of influenza $A / H 1 N 1$ infection } \\
\hline & $\mathrm{p}$ & OR $(95 \% \mathrm{Cl})$ & OR allelic $(95 \% \mathrm{Cl})$ \\
\hline CCL1 & & & $2.31(1.25-4.31)$ \\
\hline \multicolumn{4}{|l|}{ rs2282691 } \\
\hline AT & 0.85 & $1.14(0.29-4.38)$ & \\
\hline AA & 0.12 & $2.75(0.78-9.72)$ & \\
\hline$I L 1 B$ & & & $1.62(0.92-2.88)$ \\
\hline \multicolumn{4}{|l|}{ rs16944 } \\
\hline GG & 0.04 & $8.57(1.11-66.46)$ & \\
\hline$A G$ & 0.06 & $7.33(0.95-56.41)$ & \\
\hline $1 L 8$ & & & $1.45(0.80-2.63)$ \\
\hline \multicolumn{4}{|l|}{ rs4073 } \\
\hline$\Pi$ & 0.96 & $0.97(0.29-3.28)$ & \\
\hline AT & 0.17 & $1.73(0.79-3.74)$ & \\
\hline IL6 & & & $1.01(0.59-1.71)$ \\
\hline \multicolumn{4}{|l|}{ r1818879 } \\
\hline$A G$ & 0.2 & $0.61(0.29-1.30)$ & \\
\hline AA & 0.45 & $0.69(0.26-1.82)$ & \\
\hline LTA & & & $0.72(0.42-1.26)$ \\
\hline \multicolumn{4}{|l|}{ rs909253 } \\
\hline GG & 0.66 & $1.25(0.46-3.41)$ & \\
\hline$A G$ & $<0.001$ & $3.3(1.51-7.20)$ & \\
\hline TNF & & & $1.25(0.79-1.99)$ \\
\hline \multicolumn{4}{|l|}{ rs1800750 } \\
\hline AG & 0.27 & $2.54(0.49-13.24)$ & \\
\hline AA & 0.02 & $3.52(1.24-10.03)$ & \\
\hline rs1800629 & & & $1.10(0.30-3.91)$ \\
\hline$A G$ & 0.88 & $1.1(0.30-4.02)$ & \\
\hline rs361525 & & & $3.34(1.56-7.08)$ \\
\hline$A G$ & 0.37 & $0.5(0.11-2.24)$ & \\
\hline AA & $<0.001$ & $34.8(4.06-297.87)$ & \\
\hline
\end{tabular}

OR: odds ratio; Cl: confidence interval; allelic OR: comparison with ancestral gene. Results were considered statistically significant when $\mathrm{P}$ was $<0.05$.

\section{Polymorphisms and laboratory tests}

No changes in laboratory parameters were found with respect to the genotypes of the SNPs in TNF rs361525, LTA rs909253, CCL1 rs2282691, or IL6 rs1818879 (Additional file 1: Table S1). For the homozygous genotype AA of rs16944 in $I L 1 B$, an elevated number of leukocytes was found (mean: $44.9 \times 10^{3} / \mathrm{mm}^{3}$ ), whereas for the heterozygous genotype AG and the homozygous genotype $\mathrm{GG}$, the mean titer values were $8.62 \times 10^{3} / \mathrm{mm}^{3}$ and $6.96 \times 10^{3} / \mathrm{mm}^{3}$, respectively ( $\mathrm{p}<0.001$ ). The genotype AG in rs1800629 in TNF was associated with elevated levels of BUN (33mg/dl), whereas for the genotype GG, the BUN levels were lower ( $\mathrm{p}=0.05$ ) (Additional file 1: Table S1). The genotype AA of rs1800750 in TNF showed high levels of
Table 6 Risk of death from influenza A/H1N1 in relation to the different polymorphisms studied

\begin{tabular}{|c|c|c|c|}
\hline Gen/allele & $p$ & OR (Cl 95\%) & OR allelic (Cl 95\%) \\
\hline CCL1 rs2282691 & & & $1.63(0.63-4.40)$ \\
\hline AT & 0.40 & $0.4(0.07-2.79)$ & \\
\hline AA & 0.90 & $1.1(0.22-5.31)$ & \\
\hline IL1B rs16944 & & & $1.55(0.56-4.50)$ \\
\hline GG & 0.70 & $1.6(0.17-14.40)$ & \\
\hline$A G$ & 0.30 & $2.8(0.35-23.02)$ & \\
\hline IL8 rs4073 & & & $1.41(0.53-3.78)$ \\
\hline$\pi$ & 0.70 & $0.7(0.07-6.11)$ & \\
\hline AT & 0.40 & $1.7(0.51-5.76)$ & \\
\hline IL6 rs1818879 & & & $0.96(0.40-2.28)$ \\
\hline$A G$ & 0.30 & $0.5(0.15-1.70)$ & \\
\hline $\mathrm{AA}$ & 0.50 & $0.5(0.10-2.76)$ & \\
\hline LTA rs909253 & & & $0.46(0.16-1.27)$ \\
\hline GG & 0.50 & $0.5(0.05-4.27)$ & \\
\hline$A G$ & 0.06 & $3.1(0.93-10.53)$ & \\
\hline \multicolumn{4}{|l|}{ TNF } \\
\hline rs1800750 & & & $1.21(0.55-2.61)$ \\
\hline$A G$ & 0.30 & $3.5(0.39-31.76)$ & \\
\hline AA & 0.20 & $2.9(0.58-14.51)$ & \\
\hline rs1800629 & & & $2.39(0.51-11.03)$ \\
\hline$A G$ & 0.30 & $2.5(0.51-12.26)$ & \\
\hline rs361525 & & & $0.95(0.21-4.16)$ \\
\hline$A G$ & 1.00 & & \\
\hline AA & 0.40 & $2.8(0.31-24.74)$ & \\
\hline
\end{tabular}

OR: odds ratio; $\mathrm{Cl}$ : confidence intervals; allelic OR: comparison with ancestral gene. Results were considered statistically significant when $\mathrm{P}$ was $<0.05$.

CPK (mean: 2246.25 IU/L), whereas the genotypes GG and AG had mean values of $366.32 \mathrm{IU} / \mathrm{L}$ and 450.00 $\mathrm{IU} / \mathrm{L}$, respectively $(\mathrm{p}=0.05)$.

\section{Discussion}

Although it has been reported that some of the genes involved in inflammation are associated with pulmonary and infectious diseases [16,17,21,25-28], to date, no direct association between these polymorphisms and infection by influenza $\mathrm{A} / \mathrm{H} 1 \mathrm{~N} 1$ virus has been reported. In the present study, the logistic regression analysis of cases and controls showed that TNF rs361525 (AA), rs1800750 (AA), and LTA rs909253 (AG) were associated with high risk of infection by pandemic influenza A/H1N1. Although mortality of the $\mathrm{A} / \mathrm{H} 1 \mathrm{~N} 1$ patients was greater than that of the ILI patients ( $\mathrm{p}<0.001$ ), only genotype AG of LTA rs909253 demonstrated an association with mortality ( $\mathrm{p}=0.06)$ just missing being statistically significant. This finding may indicate that being a carrier of genotype AG LTA at rs909253 entails a poorer prognosis for this illness.

Some biomarkers, such as CRP, LDH, leukopenia, and hypoxemia $[7,8]$ have been considered as predictors for 
severe illness by influenza $\mathrm{A} / \mathrm{H} 1 \mathrm{~N} 1$ virus. In this study, we found that elevated values of laboratory test parameters (BUN, CPK, and leukocyte titer) were associated with TNF (rs1800629 AG, rs1800750 AA), and IL1B (genotype AA). These results may indicate that being a carrier of these polymorphisms in particular may be associated with severer organic damage by infection by influenza $\mathrm{A} / \mathrm{H} 1 \mathrm{~N} 1$ virus. However, in the case of $I L 8$, the homozygous AA appeared to offer a certain degree of protection against severe illness; this may be explained, in part, by the association of a higher concentration of oxygen in the blood $\left(\mathrm{P}_{\mathrm{a}} \mathrm{O}_{2}>60 \mathrm{~mm} \mathrm{Hg}\right)$ with this genotype.

Although susceptibility for presenting an adverse clinical course (i.e., sepsis, septic shock, multiples organ failure, or death) varies due to different degrees of inflammatory response [30], genetic factors of the host may influence the nature and intensity of this response. The present study is the first to demonstrate that the polymorphisms in genes related to the inflammatory response may, in some manner, be influencing the risk of infection by influenza $\mathrm{A} / \mathrm{H} 1 \mathrm{~N} 1$ virus and of death from this illness. One possible mechanism may be the formation of disequilibria in the bond between alleles, creating haplotypes that differentially affect the expression and activity of cytokines and chemokines, thereby resulting in a severer clinical course for the infection.

To avoid variability in our results, we studied a homogeneous population of Mexican mestizos. Although the sampling size was a limitation in our study, we were able to demonstrate statistically significant differences in the distribution of genotypes in terms of infection, mortality, and biomarkers between cases and controls, thus suggesting a strong association with the illness. However, infection by influenza $\mathrm{A} / \mathrm{H} 1 \mathrm{~N} 1$ virus is a very complex illness that involves not only the association of environmental factors and the genetic make-up and biology of the individual per se, but also the presence of comorbidities that may contribute to a greater severity of the illness $[4,5]$.

We had limitations. For example, contacts exhibited significant titers of specific anti-A/H1N1 antibodies, supporting the fact that they were in contact with the $\mathrm{A} / \mathrm{H} 1 \mathrm{~N} 1$ virus. Additionally is necessary clear that is not a patients group, we just include unrelated contacts in this study (e.g. family in law persons, home workers, etc.). They were in close contact with patients when the latter exhibited acute respiratory illness. None of these household contacts developed respiratory illness. However, the presence of antibody would not confirm infection with $\mathrm{A} / \mathrm{H} 1 \mathrm{~N} 1$ virus because there is the likelihood of cross-reactivity [33]. But, when a person with positivity of antibodies that had contact with an A/H1N1 virus infected patient, the infection cannot be excluded
[34]. The gold standard for identifying the infection to $\mathrm{A} / \mathrm{H} 1 \mathrm{~N} 1$ virus is real time PCR test; however to identify the presence of the virus in symptomatic patients is necessary that the patients be assessed during the first days from the beginning of the disease, the probability of identifying the virus by molecular test in asymptomatic patients is very low and not practical [35].

With the high mortality rate from the 2009 influenza A/H1N1 pandemic in Mexico [31], the approach used in this work could acquire great importance, as the study of polymorphisms may be useful in predicting the conduct that the infection would follow during future outbreaks of influenza A/H1N1 in Mexico.

\section{Conclusions}

The TNF polymorphisms studied were associated with risk of infection by influenza $\mathrm{A} / \mathrm{H} 1 \mathrm{~N} 1$ virus during the pandemic in Mexico in 2009. These genetic variants may contribute to the severest clinical manifestations in Mexican mestizos.

\section{Additional file}

Additional file 1: Table S1. Comparison of laboratory findings in relation to the polymorphisms studied in $\mathrm{A} / \mathrm{H} 1 \mathrm{~N} 1$ patients and controls.

\section{Abbreviations}

AHC: Asymptomatic healthy contacts; ARDS: Acute respiratory distress syndrome; BMI: Body mass index; BUN: Blood urea nitrogen;

CCL1: Chemokine (C-C motif) ligand 1; CDC, U.S: Centers for Disease Control and Prevention; Cl: 95\% Confidence interval; CPK: Creatine phosphokinase; CRP: C- reactive protein; GLR: Global lethal rate; ICU: Intensive Care Unit; IFN: Interferon; IL: Interleukin; ILI: Influenza-like illness; LDH: Lactate dehydrogenase; LTA: Lymphotoxin a; OR: Odds ratio; $\mathrm{PaO}_{2}$ : Partial pressure of oxygen in arterial blood; SNP: Single nucleotide polymorphism; TNF: Tumor necrosis factor; WHO: World Health Organization.

\section{Competing interests}

The authors declare that they have no conflict of interests.

\section{Authors' contributions}

GMG, RFV, RAGR, AC, and MCL carried out the study and participated in its design and co-ordination, in the molecular assays, and in the preparation of the manuscript. ARV participated in the design and co-ordination of the study, compiled data, and helped prepare the manuscript. MPR, CGB, CGM, VBA, and JMMA participated in the design and co-ordination of the study, carried out the study and the statistical analysis, and helped prepare the manuscript. All authors read and approved the final version of the manuscript.

\section{Acknowledgments}

This study was funded by the Consejo Nacional de Ciencia y Tecnología (CONACYT), México and by CONACyT-Básica, SALUD2009-C02-127089. and CONACYT-FOSIS SALUD2009-C02-126699. The authors thank Veronica

Yakoleff for translating the original Spanish manuscript and for helpful comments. The authors thank the Coordinación de Investigación en Salud of the IMSS for covering the cost of the translation and publication.

\section{Author details}

${ }^{1}$ Coordinación de Investigación en Salud, Instituto Mexicano del Seguro Social (IMSS), Torre Academia Nacional de Medicina 4to piso,

Av. Cuauhtémoc 330, 06720 México, DF, México. ${ }^{2}$ Instituto Nacional de Enfermedades Respiratorias Ismael Cosío Villegas, Tlalpan 4502, 14080, 
México, DF, México. ${ }^{3}$ Coordinación de Vigilancia Epidemiológica y Apoyo en Contingencias, IMSS, Mier y Pesado 120, 03100 México, DF, México.

Received: 24 February 2012 Accepted: 6 November 2012 Published: 13 November 2012

\section{References}

1. Bautista E, Chotpitayasunondh T, Gao Z, Harper SA, Shaw M, Uyeki TM, Zaki SR, Hayden FG, Hui DS, Kettner JD, Kumar A, Lim M, Shindo N, Penn C Nicholson KG: Clinical aspects of pandemic 2009 influenza A (H1N1) virus infection. N Engl J Med 2010, 362:1708-1719.

2. Singanayagam A, Singanayagam A, Wood V, Chalmers JD: Factors associated with severe illness in pandemic 2009 influenza A (H1N1) infection: implications for triage in primary and secondary care. $J$ Infect 2011, 63:243-251.

3. Chowell G, Echeverría-Zuno S, Viboud C, Simonsen L, Tamerious J, Miller MA, Borja-Aburto VH: Characterizing the epidemiology of the 2009 influenza A/H1N1 pandemic in Mexico. PLoS Med 2011, 8:e1000436.

4. Ward KA, Spokes PJ, McAnulty JM: Case-control study of risk factors for hospitalization caused by pandemic (H1N1) 2009. Emerg Infect Dis 2011, 17:1409-1416

5. Fezeu L, Julia C, Henegar A, Bitu J, Hu FB, Grobbee DE, Kengne AP, Hercberg S, Czernichow S: Obesity is associated with higher risk of intensive care unit admission and death in influenza $A(\mathrm{H} 1 \mathrm{~N} 1)$ patients: a systematic review and meta-analysis. Obes Rev 2011, 12:653-659.

6. Yu H, Feng Z, Uyeki TM, Liao Q, Zhou L, Feng L, Ye M, Xiang N, Huai Y, Yuan Y, Jiang H, Zheng Y, Gargiullo P, Peng Z, Feng Y, Zheng J, Xu C, Zhang $Y$, Shu Y, Gao Z, Yang W, Wang Y: Risk factors for severe illness with 2009 pandemic influenza A (H1N1) virus infection in China. Clin Infect Dis 2011, 52:457-465.

7. Reyes S, Montulla B, Martínez R, Córdoba J, Molina JM, Martí V, Martínez A, Ramírez P, Menéndez R: Risk factors of H1N1 etiology in pneumonia and impact on mortality. Respir Med 2011, 105:1404-1411.

8. Wen Y, Deng BC, Zhou Y, Wang Y, Cui W, Wang W, Liu P: Immunological features in patients with pneumonitis due to influenza A H1N1 infection. J Investig Allergol Clin Immunol 2011, 21:44-50.

9. To KK, Hung IF, Li IW, Lee KL, Koo CK, Yan WW, Liu R, Ho KY, Chu KH, Watt CL, Luk WK, Lai KY, Chow FL, Mok T, Buckley T, Chan JF, Wong SS, Zheng B, Chen H, Lau CC, Tse H, Cheng VC, Chan KH, Yuen KY: Delayed clearance of viral load and marked cytokine activation in severe cases of pandemic H1N1 2009 influenza virus infection. Clin Infect Dis 2010, 50:850-859.

10. Bermejo-Martin JF, de Lejarazu RO, Pumarola T, Rello J, Almansa R, Ramirez P, Martin-Loeches I, Varillas D, Gallegos MC, Serón C, Micheloud D, Gomez JM, Tenorio-Abreu A, Ramos MJ, Molina ML, Huidobro S, Sanchez E, Gordón M, Fernández V, Del Castillo A, Marcos MA, Villanueva B, López CJ, Rodríguez-Domínguez M, Galan JC, Cantón R, Lietor A, Rojo S, Eiros JM, Hinojosa C: Th1 and Th17 hypercytokinemia as early host response signature in severe pandemic influenza. Crit Care 2009, 13:R201. doi:10.1186/cc8208.

11. Michaelis M, Doerr HW, Cinatl J Jr: Of chickens and men: avian influenza in humans. Curr Mol Med 2009, 9:131-151.

12. de Jong MD, Simmons CP, Thanh TT, Hien VM, Smith GJ, Chau TN, Hoang DM, Chau NV, Khanh TH, Dong VC, Qui PT, Cam BV, Ha DQ, Guan Y, Peiris $J S$, Chinh NT, Hien TT, Farrar J: Fatal outcome of human influenza A (H5N1) is associated with high viral load of human influenza A. Nat Med 2006, 12:1203-1207.

13. Mainers TR, Szretter KJ, Perrone L, Belser JA, Bright RA, Zeng H, Tumpey TM, Katz JM: Pathogenesis of emerging avian influenza viruses in mammals and the host innate immune response. Immunol Rev 2008, 225:68-84.

14. Hagau N, Slavcovici A, Gonganau DN, Oltean S, Dirzu DS, Brezoszki ES, Maxim M, Ciuce C, Mlesnite M, Gavrus RL, Laslo C, Hagau R, Petrescu M, Studnicska DM: Clinical aspects and cytokine response in severe H1N1 influenza A virus infection. Crit Care 2010, 14:R203. doi:10.1186/cc9324.

15. Wang B, Wang J, Zheng Y, Zhou S, Zhen J, Wang F, Ma X, Zeng Z, HBV Study Consortium: TNF-alpha-238 and -308 polymorphisms with different outcomes of persistent hepatitis B virus infection in china. Pathology 2010, 42:674-680.

16. Alssani B, Ogwaro KM, Shrestha S, Tang J, Breen EC, Wong HL, Jacobson LP, Rabkin CS, Ambinder RF, Martinez-Maza O, Kaslow RA: The major histocompatibility complex conserved extended haplotype 8.1 in
AIDS-related non-Hodgkin lymphoma. J Acquir Immune Defic Syndr 2009, 52:170-179.

17. Gaudet MM, Egan KM, Lissowska J, Newcomb PA, Brinton LA, Titus-Ernstoff L, Yeager M, Chanock S, Welch R, Peplonska B,

Trentham-Dietz A, Garcia-Closas M: Genetic variation in tumor factor and lymphotoxin-alpha (TNA-LTA) and breast cancer risk. Human Genet 2007, 121:483-490.

18. Partida-Rodriguez O, Torres J, Flores-Luna L, Camorlinga M, Nieves-Ramirez M, Lazcano E, Perez-Rodriguez M: Polymorphism in TNF and HSP-70 show a significant association with gastric cancer and duodenal ulcer. Int J Cancer 2010, 126:1861-1868.

19. Ned RM, Yesupriya A, Imperatore G, Smelser D, Moonesinghe R, Chang MH, Dowling NF: nflammation gene variants and susceptibility to albuminuria in U.S. population: analysis in the Third National Health and Nutrition Examination Survey (NHANES III), 1991-94. BMC Med Genet 2010, 11:155.

20. Martinez-Carrillo DN, Garza-Gonzalez E, Betancout-Linares R, Mónico-Manzano T, Antúnez-Rivera C, Roman-Roman A, Flores-Alfaro E, Illades-Aguiar B, Fernández-Tilapa G: Association of ILB -511C/-31T haplotypes and Helicobacter Pylori VacA genotypes with gastric ulcer and chronic gastritis. BMC Gastroenterol 2010, 10:126.

21. Vazarova B, Fernádez-Real JM, Knoweler WC, Gallart L, Hanson RL, Guber JD, Ricart W, Vendrell J, Richart C, Tataranni PA, Wolford JK: The interleukin-6 $(-174) \mathrm{G} / \mathrm{C}$ promoter polymorphism is associated with type-2 diabetes mellitus in Native Americans and Caucasians. Hum Genet 2003, 112:409-413.

22. Qi L, Zhang C, van Dam RM, Hu FB: Interleukin-6 genetic variability and adiposity: association in two prospective cohorts and systematic review in 26,944 individuals. J Clin Endocrinol Metab 2007, 92:3618-3625

23. Cheng CH, Lee YS, Tsau YK, Lin TY: Genetic polymorphisms and susceptibility to parenchymal renal infection among pediatric patients. Pediatr Infect Dis J 2011, 30:309-314.

24. Heinzmann A, Ahlert I, Kurtz T, Berner R, Deichmann KA: Association study suggests opposite effects of polymorphism within IL8 on bronchial asthma and respiratory syncytial virus bronchiolitis. J Allergy Clin Immunol 2004, 114:671-676.

25. Hacking D, Knight JC, Rockett K, Brown H, Frampton J, Kwiatkowski DP, Hull J, Udalova IA: Increased in vivo transcription of an IL-8 haplotype associated with respiratory syncytial virus disease-susceptibility. Genes Immun 2004, 5:274-282.

26. Hull J, Thomson A, Kwiatkowski D: Association of respiratory syncytial virus bronchiolitis with the interleukin 8 gene region in UK families. Thorax 2000, 55:1023-1027.

27. Takabatake N, Shibata Y, Abe S, Wada T, Machiva J, Igarashi A, Tokairin Y, Ji G, Sato H, Sata M, Takeishi Y, Emi M, Muramatsu M, Kubota I: A single nucleotide polymorphism in the CCL1 gene predicts acute exacerbations in chronic obstructive pulmonary disease. Am J Respir Crit Care Med 2006, 174:875-885.

28. Camarena A, Juárez AM, Estrada A, Carrillo G, Falfán R, Zuñiga J, Navarro C, Granados J, Selman M: Major histocompatibility complex and tumor necrosis factor-a polymorphisms in pigeon breeder's disease. Am J Respir Crit Care Med 2001, 163:1528-1533.

29. Nieves ME, Partida O, Alegre P, Tapia MC, Pérez M: Characterization of single-nucleotide polymorphisms in the tumor necrosis factor a promoter region and lymphotoxin $a$ in squamous intraepithelial lesion, precursors of cervical cancer. Transl Oncol 2011, 4:336-344.

30. Paskullin DD, Fallavena P, Paludo F, Borges T, Picanco J, Dias F, Alho C: TNF -308G > a promoter polymorphism ( $r s 1800626$ ) and outcome from critical illness. Braz J Infec Dis 2011, 15:231-238.

31. Echevarría-Zuno S, Mejía-Aranguré JM, Mar-Obeso AJ, Grajales-Muñiz C, Robles-Pérez E, González-León M, Ortega-Alvarez MC, Gonzalez-Bonilla C, Rascón-Pacheco RA, Borja-Aburto VH: Infection and death from influenza A H1N1 virus in Mexico: a retrospective analysis. Lancet 2009, 374:2072-2079.

32. WHO information for laboratory diagnosis of pandemic (H1N1) 2009 virus in humans-update; 2009. http://www.who.int/csr/resources/publications/ swineflu/WHO_Diagnostic_RecommendationsH1N1_20090521.pdf (accessed May 26, 2009).

33. Hancock K, Veguilla V, Lu X, Zhong W, Butler EN, Sun H, Liu F, Dong L, DeVos JR, Gargiullo PM, Brammer TL, Cox NJ, Tumpey TM, Katz JM: Cross- 
reactive antibody responses to the 2009 pandemic H1N1 influenza virus. N Engl J Med 2009, 361:1945-1952.

34. Baguelin M, Hoschler K, Stanford E, Waight P, Hardelid P, Andrews N, Miller E: Age-specific incidence of A/H1N1 2009 influenza infection in England from sequential antibody prevalence data using likelihood-based estimation. PLoS One 2011, 6:e17074

35. Papenburg J, Baz M, Hamelin MĖ, Rhéaume C, Carbonneau J, Ouakki M, Rouleau I, Hardy I, Skowronski D, Roger M, Charest H, De Serres G, Boivin G: Household transmission of the 2009 pandemic A/H1N1 influenza virus: elevated laboratory-confirmed secondary attack rates and evidence of asymptomatic infections. Clin Infect Dis 2010, 51:1033-1041.

doi:10.1186/1471-2334-12-299

Cite this article as: Morales-García et al:: Pandemic influenza A/H1N1 virus infection and $T N F, \angle T A, I L 1 B, I L 6, I L 8$, and $C C L$ polymorphisms in Mexican population: a case-control study. BMC Infectious Diseases 2012 12:299.

\section{Submit your next manuscript to BioMed Central and take full advantage of:}

- Convenient online submission

- Thorough peer review

- No space constraints or color figure charges

- Immediate publication on acceptance

- Inclusion in PubMed, CAS, Scopus and Google Scholar

- Research which is freely available for redistribution 